2. Бушанський В. Місто мертвих. Електронний ресурс. Режим доступу: https://life.pravda.com.ua/columns/2011/07/1/81107/.

3. Галич О. А. Історія літературознавства : підручник / О. А. Галич. Київ: Либідь, 2013. 392 с.

4. Жадан С. Ворошиловград: роман. Харків: «Фоліо», 2010. 442 с.

5. Жадан С. Інтернат: роман. Чернівці : Меридіан Черновіц, 2017. $336 \mathrm{c}$.

6. Романець В. А. Психологія творчості: Навч. посібник.2-ге вид., доп. Київ: Либідь, 2001. 288 с.

7. Філософія історії: Підручник для вищих шкіл. Харків: Прапор, 2006. 565 c.

DOI https://doi.org/10.30525/978-9934-588-90-7-18

\title{
СОЦІАЛЬНА ТА ПСИХОЛОГІЧНА ДЕТЕРМІНАЦІЯ ЗЛОЧИНУ В ПОВІСТІ «НЕНАВИСТЬ ДО БЛИЖНЬОГО» МИХАЙЛА ГАФІЇ ТРАЙСТИ
}

\author{
Вотьканич М. I. \\ аспірант, \\ викладач кафедри украӥнської літератури \\ Ужггородський національний університет \\ м. Ужгород, Україна
}

Михайло Гафія Трайста - український письменник, що живе та працює в Румунії. Його активна громадська діяльність сприяє активізації культурних контактів України та української меншини Румунії.

Літературна творчість М. Трайсти $є$ гідним продовженням української письменницької традиції на румунських теренах. Прозовий доробок митця розмаїтий за жанрово-стильовими й тематичними векторами.

Нашу увагу, зокрема, привернула перша прозова збірка письменника «Гуцульська душа», що вийшла в Бухаресті у 2008 році. Книгу складають десять оповідань та дві повісті. Події у творах збірки розгортаються переважно в реалістичному ключі, тематично ж їх об'єднує інтерпретація автором кримінальних мотивів. Сюжетотворчою $\epsilon$ ця тема й у повісті «Ненависть до ближнього», що стала об'єктом нашого дослідження. 
Мета розвідки - розгляд соціальних та психологічних детермінант злочину в аналізованому творі.

Загалом творчість М. Трайсти була об'єктом дослідницьких студій В. Антофійчука, I. Ребошапки, Л. Повх-Ходанич, П. Ходанича, М. Якубовської, М. Гербіл, К. Ірода, С. Ткачука та ін.

О. Масляник, зокрема, відзначає майстерність прозового почерку автора: «Трайста - видатний прозаїк, тонкий психолог, я б сказав, психоаналітик. Він добре знає глибинні глибини людської душі» [3].

Однак комплексне осмислення художнього світу М. Трайсти ще не здійснено. 3 огляду на це запропонована тема $є$ актуальною.

У центрі сюжету повісті «Ненависть до ближнього» - конфлікт двох родин: сім'ї бідних селян Сурдуків та сім'ї багатого газди Петра Клонца, який палає ненавистю та презирством до незаможної родини. Такі почуття персонажа зумовлені конкуренцією сина Клонца - Якова 3 сином Анни Сурдучки Максимом, що триває ще 3 дитинства: «Максима відразу полюбили всі, бо він був чемним і слухняним. Багато разів ставав прикладом для класу або для всієї школи, на відміну від свого односельчанина Якова Клониа, який був тупим на голову, як дерев'яна сапа, тільки за гроші та хабарі вдалося старому Клониу тримати його в школі. Петро Клони казився від злості, коли викладачі за добру науку хвалили Максима Сурдука, а його Якова картали за лінивство $i$ страменну його неслухняність» [4, с. 149-150].

Ситуація досягає апогею під час приїзду до рідного села юнаків кількох професорів із міста Клужа, де хлопці готуються до лікарської діяльності. Клонц, користуючись моментом, надіється шляхом підлабузництва й підкупу залагодити проблеми сина 3 навчанням, але отримує відмову. На додачу розуміє, що поважні гості нехтують його гостинністю та віддають перевагу ночівлі в домі Максима Сурдука. Ці події акумулюють нагромаджені роками негативні почуття та емоції старого Клонца, і він вирішує позбутися Максима: намовляе свого наймита Дмитра вбити хлопця під час полювання.

Рішення щодо скоєння злочину герой приймає легко. Автор не показує нам вагання або сумніви персонажа. Він немає жодних докорів сумління чи внутрішньої боротьби. Це свідчить про те, що Клонц не вперше переступає межу закону. Читачеві зрозуміло, що Петро Клонц схильний до вчинків кримінального характеру завдяки його самохарактеристиці. Персонаж у розмові $з$ наймитом Дмитром вдається до спогадів: «Коли ми ходили браконувати, я запримітив, що ти дуже вправно виіляєщ!» [4, с. 179]. 
Отже, старий Клонц - хабарник і браконьєр. Але у творі автор фокусує свою увагу на задумі страшного злочину - вбивства. М. Трайста не подає нам докладний життєпис персонажа, ми не бачимо його у розвитку. Але промовистою $є$ авторська характеристика: «Клонц заподіяв багато лиха, забираючи то в одного, то в другого ба клаптик землі, ба клин лісу, не зважсаючи ні на сльози сиріт, ані на прокльони вдовиць, лише ради власного збагачення» [4, с. 173-174].

Як відомо, рушійною силою скоєння будь-якого злочину є наявність мотиву. Більшість неправомірних дій персонажа продиктовані незадоволеністю своїм соціальним становищем, прагненням до постійного примноження статків, а як наслідок - впливовості та влади. За спостереженнями італійського кримінолога Ч. Ломброзо, поряд із бідністю багатство теж часто веде до злочинів проти чужої власності, мотивами яких є марнославство, бажання перевершити інших (переклад 3 російської-наш) [2, с. 95-96].

Багатство нерідко породжує також почуття вседозволеності й зверхності. Це зумовлює і психологічний детермінант злочинної поведінки персонажа: Клонц не може змиритися 3 тим, що хлопець із бідної селянської сім’ї має талант до навчання, заслужив повагу й прихильність викладачів та інших студентів, а його сина постійно критикують.

За спостереженнями В. І. Батова та Н. Я. Константинової, «порівняно із законослухняними громадянами самооцінка у злочинців за морально-етичними якостями завищена щонайменше у два рази» [цит. за: 1, с. 224]. Цю тезу підтверджує такий внутрішній монолог персонажа повісті М. Трайсти: «Аби ви знали, щяо Петра Клонща ніхто не переможе!» [4, с. 183].

Внутрішній голос Петра відіграє важливу роль у розумінні мотивів його злочинної поведінки. Герой часто пригадує випадки, коли Максим виявився кращим, ніж його Яків, згадує пригоду з братом Максима Іваном, злиться через невдалу розмову з професором Станеску. Думки чи не найкраще ілюструють внутрішній світ персонажа. «Властиво, у внутрішньому мовленні відбувається саморозкриття характеру злочинця, процес мотивації вчинків і зображення динаміки почуттів» [5, с. 193], зазначає А. Швець.

Якраз через внутрішні монологи героя можемо простежити наростання згубного почуття в душі Клонца: ненависть розриває його зсередини. Виникає враження, що вона персоніфікується в образ якоїсь надприродної сили, що бере верх над усією істотою героя. Для психологізації цього образу автор використовує біблійний мотив за принципом антитези: «ненависть до ближнього» як рушійний 
детермінант гріховного життя протиставляється християнській ідеї «любові до ближнього». Саме почуття зверхності й ненависті, на наш погляд, штовхають Петра Клонца на злочин - замовлення вбивства шляхом підкупу наймита Дмитра.

Дмитро Юфурко - ще один персонаж, який у повісті «Ненависть до ближнього» втілює образ злочинця. Як зазначено у творі, Петро Клонц і Дмитро Юфурко були варті один одного. Але в цьому випадку автор подає деякі передумови становлення особистості Дмитра: він походив із роду, який у селі не любили і якого боялися: «Юфурки робили лихо людям лише для власного задоволення, просто їм подобалося робити зло» [4, с. 174]. Дмитро давно працював на Клонца і виконував різні доручення, у тому числі - «брудні», злочинні. I на цей раз він дає згоду втілити задум Клонца в життя, але, як виявляється, тільки для того, щоб врятувати життя невинного хлопця. Він попереджує про страшний задум сім’ю Сурдуків.

Важливим детермінантом такого вчинку персонажа $\epsilon$ внутрішній цензор героя: попри те, що він виріс у несприятливій атмосфері, напучування матері все ж залишили слід у його душі: «... моя мати завжди говорила мені, коли брати чинили людям зло: «Ти не такий, Дмитре, як вони, ти не можеш чинити людям зло, ти не такий!». Мати була права» [4, с. 189].

У творі спостерігаємо й елементи детективного жанру, про що свідчить наявність мотиву злочину та покарання, загадки й інтриги. Хоча читачеві відома особа злочинця, автору вдається тримати напруження до останніх рядків: постріл пролунав, але чи відбулося вбивство, чи скоєно злочин, чи залишився живим Максим? Відповіді на ці питання отримуємо далеко не одразу: тільки зі слів представників органів правопорядку стає відомо про рішення Дмитра та інсценізацію злодіяння.

Отже, у повісті «Ненависть до ближнього» М. Трайста художньо розгортає повчально-захопливу історію, у якій показово відображається психологія двох типів злочинців. Автор умотивовує вибір кожного 3 персонажів соціальними та власне психологічними чинниками. 3 цією метою він застосовує такі прийоми, як авторські характеристики, оцінка персонажа іншими героями, внутрішні монологи, сюжетні колізії 3 елементами детективності.

\section{Література:}

1. Головкін Б. М., Наваляна Я. Т. Психологічні особливості злочинців. Форум права. 2012. № 4. С. 223-230. 
2. Ломброзо Ч. Преступный человек. М., 2005. 880 c. URL: https://asagao.nethouse.ru/static/000/000/298/767/doc/f4/74/af689ff077b64c3e c4a973d1 efb24d8f83e2.pdf (дата звернення: 21. 10. 2020).

3. Масляник O. Деміург 3 Мараморощини. URL: http://zolotapektoral.te.ua/деміург-3-мараморощини/\%20(дата\%20 звернення:\%2019.\%2010.\%202020).

4. Трайста М. Гуцульська душа. Бухарест: RCR Editorial, 2008. 356 с.

5. Швець А. I. Злочин і катарсис: Кримінальний сюжет і проблеми художнього психологізму в прозі Івана Франка / відп. ред. Є. К. Нахлік. Львів, 2003. 236 с.

DOI https://doi.org/10.30525/978-9934-588-90-7-19

\title{
«ХОЧУ ЖИТИ БІЛЯ МОРЯ»: ТЕРАПЕВТИЧНИЙ ВПЛИВ МОРСЬКОГО УЗБЕРЕЖЖЯ У РОМАНІ «СІЛЬ ДЛЯ МОРЯ, АБО БІЛИЙ КИТ» А. НІКУЛІНОЇ
}

\author{
Грищенко О. В. \\ кандидат філологічних наук, \\ дочент кафедри журналістики, \\ проректор з наукової роботи \\ Міжнародний класичний університет імені Пилипа Орлика \\ м. Миколаїв, Україна
}

Сучасна українська письменниця Анастасія Нікуліна написала важливий роман для українського суспільства. Це історія про підлітків із їхніми проблемами, зокрема, суїцидальними настроями. Її дебютна книжка «Сіль для моря, або Білий Кит» (2017) - це спроба зазирнути у внутрішній світ підростаючого покоління, розібратися у проблемних ситуаціях та знайти правильні рішення. У своєму соціальнопсихологічному романі авторка пропонує декілька варіантів виходу із кризової ситуації. Це і підтримка оточуючих, підліткове кохання, нові знайомства, онлайн спілкування тощо. Але, на наш погляд, найцікавішим методом морально-психологічної терапії героїв у романі «Сіль для моря, або Білий Кит» постає лікування морем, або таласотерапія.

За канонами масової літератури авторка використала у сюжеті твору чи не найпривабливіші фабульні моменти: красиве життя заможних дітей, почасти ідеальні портрети, перше кохання, популярність серед однолітків, гаджети тощо. Але за цією красою криються значно 